\title{
18
}

\section{Development of a Management Tool for Vegetative Filter Strips}

\author{
B. Gharabaghi, R. P. Rudra, H. R. Whiteley, and W. T. Dickinson
}

Vegetative filter strips (VFS) are widely advocated as a BMP to safeguard and /or remediate water quality in streams. This study provides management tools for specification of vegetative filter strips based on the site-specific soil, land use, land management, and topography of the upland area. The developed computer models will be useful to consulting engineers, extension engineers and other water management specialists working with farmers and other landowners to reduce the discharge of pollutants into adjacent streams and creeks. Comprehensive field experiments have been conducted to quantify the performance of VFS under different flow conditions, pollutant loads, and vegetation covers (Gharabaghi et al., 2000a, 2000b, 2001a, and 2001b). An agricultural non-point source pollution model is adapted and validated for Ontario conditions to determine different cropland runoff, sediment, nutrients and bacteria loads from upland agricultural areas based on their individual characteristics. A vegetative filter strip model is being validated for Ontario conditions; it describes the transport of sediment, nutrients and bacteria through VFS. The non-point source pollution model will be combined with the VFS model to form a design tool for vegetative filter strips to achieve management objectives for reduction of non-point source pollution. A userfriendly, interactive version of the computer management tool is being developed suited for use by agricultural and environmental field personnel.

Gharabaghi, B., R. Rudra, H.R. Whiteley and W.T. Dickinson. 2002. "Development of a Management Tool for Vegetative Filter Strips." Journal of Water Management Modeling R208-18. doi: 10.14796/JWMM.R208-18.

(c) CHI 2002 www.chijournal.org ISSN: 2292-6062 (Formerly in Best modeling practices for Urban Water Systems. ISBN: 0-9683681-6-6) 


\subsection{Introduction}

The value of VFS for protection and enhancement of the quality of stream ecosystems has been examined extensively (Wilson and Imhof, 1998). In appropriate settings, grass filter strips can provide slope stabilization and reduction in sediment and pollutant loads entering streams. A study by the Pollution from Land Use Activities Reference Group (PLUARG), of the International Joint Commission (IJC-PLUARG, 1987), focused attention on the effects on receiving water of non-point source (NPS) pollution. Since then NPS pollution has been an important part of studies of water quality in the Great Lakes watershed. Studies in other watershed areas such as Chesapeake Bay have given similar emphasis to NPS control as a necessary step to improved water quality. Efforts to reduce NPS pollution were first aimed at minimizing erosion from agricultural lands through improvements in land management practices. Later, means of runoff treatment at field edges using sediment-control structures and VFS were considered. In the USA, since 1988, VFS are an approved USDA cost-share practice under the conservation reserve program of the 1985 Food Security Act.

The United States and Canada have over seven million $\mathrm{km}$ of rivers. In the USA the 1992 National Water Quality Inventory of over one million $\mathrm{km}$ of river stated that only $56 \%$ of the reaches surveyed fully supported multiple uses, including drinking water supply, fish and wildlife habitat, recreation, and agriculture, as well as flood prevention and erosion control. In the remaining $44 \%$ of stream miles inventoried, streambank erosion, sedimentation and excess nutrients were the most significant causes of degradation (Applied Research Systems, Inc., 1999).

In 1999 the province of Prince Edward Island, Canada, passed legislation requiring vegetative buffers for all watercourses in the province. In Ontario, the feasibility of installing a comprehensive program of stream-buffer enhancement is being considered by a consortium of stakeholder groups.

In April 1997, USDA officially launched the new National Conservation Buffer Initiative to improve soil, air, and water quality and to enhance wildlife habitat. Help was pledged to landowners in both rural and urban settings with the goal of 3.2 million $\mathrm{km}$ ( 2 million miles) of buffer strips to be installed along waterways by 2002 . To date, this program has installed over one million $\mathrm{km}$ of buffer strips along streams, with an average width of $10 \mathrm{~m}$. This initiative is led by the Natural Resources Conservation Service in cooperation with the Agricultural Research Service, Farm Service Agency; Forest Service; Cooperative State Research, Education, \& Extension Service; State Conservation

Agencies; and numerous other public and private partners (Federal Interagency Stream Restoration Working Group, 1999). 


\subsubsection{Background and Literature Review}

There is an extensive literature on VFS; some primary sources are: Wilson (1967), Neibling and Alberts (1979), Bingham et al. (1980), Young et al. (1980), Overcash et al. (1981), Wall et al. (1982), Hayes et al. (1984), Rudra and Wall (1986), Dillaha et al. (1988 \& 1989), Magette et al. (1989), Parsons et al. (1990), Choi (1992), Mickelson and Baker (1993), Smith et al. (1993), Coyne et al. (1995 \& 1998). Recent reporting of results include: Daniels and Gilliam (1996), Edwards et al. (1996 \& 1997), Hill (1996), Robinson et al. (1996), Srivastava et al. (1996), Van Dijk et al. (1996), Patty et al. (1997), Lalonde (1998), Lim et al. (1998), Moore Jr. (1998), Barfield et al. (1998), Boyd et al. (1999), Schmitt et al. (1999), Oelbermann and Gordon (2000), and Gharabaghi, et al. (2000 \& 2001). The experiments reported deal with VFS with lengths of flowpath ranging from less than one meter to more than thirty meters, slopes ranging from $2 \%$ to $16 \%$ and various types of grasses and pollution load. Runoff was either generated by real or simulated rainfall on erosion plots upstream of the VFS or by mixing soil, water and pollutants with controlled proportions in a mixing tank and distributing the slurry (i.e. artificial runoff) with a controlled flow rate at the upstream of the VFS. Performance of the VFS in treatment of runoff was often evaluated based on comparing the pollutant concentrations in runoff samples at the inlet and outlet of the VFS.

The main function of the VFS is to provide flow resistance, that is, much higher than the flow resistance along the upland flowpath. The higher resistance reduces flow velocity and sediment transport capacity of the overland flow within the VFS, resulting in considerable removal of sediments and attached pollutants through deposition from overland flow. Some removal of soluble pollutants also occurs; but infiltration not deposition is the primary mechanism for removal of soluble pollutants from overland flow. The measured removal efficiency for total suspended solids (TSS) typically varies from 50 to $98 \%$ while removal efficiency for total phosphorus (TP) is somewhat lower (30 to $70 \%$ ). The removal efficiency is found to be higher in wider strips (i.e. longer flowpaths) mainly due to an increased proportion of inflow taken out by infiltration within the strip. In general, field experiments show that even relatively short grass filter strips (i.e. $5 \mathrm{~m}$ flowpath length) can markedly improve quality of runoff by reducing pollutants such as sediments, phosphorus, nitrogen, and bacteria. In this chapter, results from the field experiments on VFS and management recommendations drawn from these results are discussed. The utility of the results in validation and modification of existing VFS models is considered. Finally, linking a non-point source pollution model with the VFS model is considered to form a design tool for VFS to achieve management objectives for reduction of non-point source pollution. 


\subsection{Results}

\subsubsection{Cycle of Field Experiments on VFS}

Field experiments were conducted at the Guelph Turf Grass Institute and Environmental Research Centre, Guelph, Ontario, Canada during August and September, 2000, to compare the runoff treatment performance of VFS under various flow and pollution load conditions. The vegetation cover for the filter strips was perennial rye grass (Lolium perenne L.). Effects of flowpath length and flow rate on performance of the filter strips in runoff treatment were studied through a comparison of test results for $2.44,4.88,9.67$ and $19.52 \mathrm{~m}$ long filter strips and flow rates per unit width of $0.25,0.54,0.80$ and $1.67 \mathrm{Ls}^{-1} \mathrm{~m}^{-1}$. The plots were $1.2 \mathrm{~m}$ wide, and parallel to each other with a slope of $5.1 \%$ to $7.2 \%$. Water was supplied to two large constant head tanks located upstream of the plots. High clay content topsoil was brought from the Harrow Research Station, Essex County, near Windsor, Ontario. The soil was air dried, ground, and mechanically sieved through a $2-\mathrm{mm}$ size mesh. Batches of soil with fixed mass $(0.5,1.0,2.0,4.0$ and $8.0 \mathrm{~kg})$ were prepared and stored in plastic bags.

For each run, a soil slurry was prepared by mixing a selected mass of soil with clear water in a mixing column using high-pressure air nozzles. The constant-concentration slurry was fed at a set rate, using peristaltic pumps, into a steady-rate inflow of clear water upstream of the plots. The plots were prewetted with clear water for about an hour before the tests began so that a steadystate infiltration rate was reached. Flow depth within the VFS was measured near the upstream edge, at mid-length and near the outlet of the strip and the travel time (residence time) was determined as the ratio of volume of resident water in the VFS to flow rate at inlet. The duration of each run was at least three times the travel time to guarantee that the concentration of suspended sediments at the VFS exit had reached a steady-state condition. A 15-min clear water flow was introduced between consecutive runs to wash-off residual loose sediments and pollutants remaining in the VFS from the preceding run.

In addition to flow rate measurement, two runoff samples were collected for each run at the upstream end and two at the downstream end of the filter strip, and these samples were preserved and later analyzed. One sample was tested for Total Suspended Solids (TSS) concentration, and other for aggregate size analysis. For TSS measurement, the sample was filtered through a 0.45micron filter, oven-dried at $105^{\circ} \mathrm{C}$ and weighed using an accurate scale. Total sediment load entering and leaving the VFS was calculated based on observed values of TSS concentration and runoff flow rate. The sediment removal efficiency of the VFS was then calculated by comparing the sediment loads at the inlet and outlet of the VFS. 
For aggregate size analysis, samples were first filtered through a $0.45-$ micron filter, and the residue on the filter was analyzed for aggregate size distribution using a Malvern MasterSizer (Laser Scattering based Particle Sizer). By comparison of aggregate-size distributions at the inlet and outlet the removal efficiency for different aggregate-size ranges was determined. This information is critical for extension of results (i.e. computing sediment-removal efficiency of VFS) from the present study to other sites and other soils (i.e. different aggregate-size distributions).

From this cycle of field experiments on VFS we determined that the first $5 \mathrm{~m}$ of the filter strip is critical for removal of suspended sediments. Almost all of the easily removable particles (i.e. particles larger that 40 microns in diameter) can be captured within the first few meters of the filter strip. However, the remaining small size particles are very difficult to remove by filtering through grass since very little turbulent energy in water is enough to keep the sediments in suspension. The only mechanism that helped in removal of small size sediments was infiltration. Vertical filtering of flow through soil can remove a major portion of small size particles (i.e. particles between 2 and 40 microns). Hence, during runs with low to moderate flow rates on longer plot lengths (e.g. $20 \mathrm{~m}$ wide filter strips), and because infiltration becomes more appreciable for these conditions, $90 \%$ or higher removal efficiencies could be achieved. The sediment-removal efficiency of VFS would not increase much by increasing the flow-path length of the filter strip beyond $10 \mathrm{~m}$. However, the gradual clogging process of the filter strips due to deposition of sediments should be taken into account and the VFS width should be designed to be long enough to perform with optimum efficiency throughout its life expectancy.

\subsubsection{Selection of Upland NPS model}

The agricultural research communities have developed a significant body of knowledge for estimating chemical runoff and soil erosion from agricultural lands, and evaluation of the resulting water quality conditions. These non-point source (NPS) pollutant models range from simple annual average "loading functions" based on the universal soil loss equation (USLE) to detailed process simulation models. The primary differences between NPS pollutant models are in the temporal and spatial detail of the analysis, and representation of the processes that determine non-point pollutant loading.

During the 1970's and early 1980's the EPA sponsored the development and testing efforts for the Hydrologic Simulation Program FORTRAN (HSPF) model (Johanson et al., 1984). The focus of the HSPF model is the ability to represent contributions of sediment, pesticides, and nutrients from agricultural areas, and evaluate resulting water quality conditions at the watershed scale 
considering both non-point contributions and in-stream water quality processes. Coincident with the HSPF development, the USDA through the Agricultural Research Service (ARS) developed the Chemicals, Runoff, and Erosion from Agricultural Management Systems (CREAMS) model (Kinsel, 1980).

CREAMS and HSPF both simulate land surface and soil profile chemicals/ biological processes that determine the fate and transport of pesticides and nutrients. The two models differ primarily in their scope and level of detail. HSPF was developed with an emphasis on watershed-scale modeling and includes both runoff and hydraulic routing needed for large watersheds and river basins. On the other hand, in CREAMS the emphasis is on representing soil-profile and field-scale processes and allows detailed representation of fieldbased agricultural management systems such as field terraces, drainage systems, field topography, and associated soil erosion processes. In CREAMS a detailed hydrology option is available, requiring short-time-interval rainfall data, or the popular SCS Curve Number procedure can be used with daily rainfall data. Because of its field-scale focus, CREAMS is limited to representing only surface runoff contributions; subsurface and leaching losses of chemicals are simply removed from the system.

The ANSWERS model (Areal Non-point Source Watershed Environment Response Simulation) developed by Beasley and Hoggins (1981) at Purdue University differs from most other NPS models in that it is a single storm event, distributed-parameter model as opposed to continuous simulation and lumped parameter model such as CREAMS and HSPF. The ANSWERS model imposes greater computational burden and spatial data requirements, thus limiting its value as an operational model. The ANSWERS model is primarily a runoff and sediment model; the nutrient simulation is based on a simple correlation between sediment yield and runoff volume; soil nutrient processes are not simulated.

The AGNPS (Agricultural Non-Point Source Pollution) model was developed initially as an event-based distributed model that simulates surface runoff, sediment and nutrient transport primarily from agricultural watersheds (Young et al., 1986). In AGNPS the watershed is subdivided into "cells" and watershed characteristics and other model inputs are expressed at cells. The model therefore has the ability to evaluate water quality characteristics at intermediate points throughout the watershed. Runoff volume and flow rate are estimated using the SCS curve number method (USDA-SCS, 1972); upland erosion and sediment transport are estimated using a modified form of the Universal Soil Loss Equation (Wischmeier and Smith, 1978); and chemicals transport is estimated based on equations adopted from CREAMS model. A continuous-intime version of AGNPS called AnnAGNPS (Srivastava et al., 1999) is now available. 
Munoz-Carpena and Parsons (2000) developed an upland hydrology (UH) utility, to produce the required input files (such as rainfall hyetograph, field inflow hydrograph and field sediment inflow and characteristics) for the vegetative filter strip model VFSMOD (Munoz-Carpena and Parsons, 1999). The UH utility computes the total runoff from the source area using the SCS Curve Number method. The time of concentration, peak runoff rate and time of peak is computed by the SCS TR55 method. The SCS unit hydrograph theory is used to estimate the runoff hydrograph. An idealized rainfall hyetograph is generated from the SCS storm type. Modified Universal Soil Loss Equation (MUSLE) is then used to estimate the sediment loss from the source area for the storm. The sediment loss is partitioned into silt and clay based on the soil particle size distribution in the top soil. The average concentration in runoff then is estimated based on the total runoff and distribution of soil particles in the sediment loss. The major limitation of the UH utility in its current version is the absence of simulation of soil nutrient processes and chemical transport.

All of the above mentioned Non-Point Source Pollution models (namely, HSPF, CREAMS, ANSWERS, AGNPS, and UH utility) estimate upland erosion and sediment transport using a modified form of the Universal Soil Loss Equation (Wischmeier and Smith, 1978). HSPF, ANSWERS and AGNPS are distributed-parameter models and impose greater computational burden and spatial data requirements compared to CREAMS and UH utility, which are lumped-parameter models. The UH utility implements useful capabilities of several models in one package, however, the current version is still in the early stages of development and does not take advantage of full potentials of a nonpoint source model such as the CREAMS model. Hence, the optimum upland NPS model for VFS study would be a modified version of the UH utility, which can handle sediment adsorbed contaminants such as phosphorous. The modification of the UH utility will be based on the soil nutrient processes and chemicals transport concepts implemented in the CREAMS model.

\subsubsection{Selection of Vegetative Filter Strip (VFS) Model}

Most of the work involving the development of analytical procedures to model VFS has been done at the University of Kentucky, for erosion control in surface mining areas (Barfield et al., 1979, Hays et al., 1979, 1984, Tollner et al., 1977, 1982). These researchers developed and tested a model (GRASSF) for filtration of suspended solids by artificial grass media. This physically-based model takes into account a number of important field parameters that affect sediment transport and deposition through filter (sediment type and concentration, vegetation type, slope and length of the filter). Wilson et al. (1981) modified and incorporated GRASSF into SEDIMOT II, a hydrology and sedimentology 
watershed model. SEDIMOT II does not handle time-dependent infiltration, an accurate description of flow through the filter, and changes in flow derived from sediment deposition during the storm event.

Williams and Nicks (1988) attempted to use CREAMS as a tool for evaluating buffer strips. They evaluated CREAMS for a 1.6 ha wheat field in Oklahoma using buffer strip widths of 3-15 m, and slopes of $2-10 \%$. The authors concluded that CREAMS is a "useful tool" for evaluating vegetative filter strip effectiveness in reducing sediment yield.

Many researchers including: Young et al. (1980), Daniels and Gilliam (1989), Dillaha et al. (1989), Magette et al. (1989), and Bolton et al. (1991) have studied the effectiveness of grass filter strips in trapping sediment and nutrients through laboratory or field experiments. They reported trapping efficiencies exceeding $50 \%$ for sediment and nutrients adsorbed to sediments such as phosphorous, while trapping of dissolved nutrients was less efficient.

Munoz-Carpena et al. (1999) have recently developed the VFSMOD model. The improvements of VFSMOD model over the GRASSF and SEDIMOT II models are the inclusion of: (i) state of the art description of flow through the filter; (ii) changes in flow derived from sediment deposition; (iii) physically based time dependent soil water infiltration; (iv) handling of complex storm pattern; and (v) varying surface conditions (slope and vegetation) along the filter. The vegetative filter strip model VFSMOD (Munoz-Carpena et al., 1999) was found to be the most advanced and comprehensive model for VFS analysis and was selected for this study.

\subsubsection{Sensitivity Analysis and Evaluation of NPS and VFS Models in Ontario Conditions}

A sensitivity analysis was performed to gain insight in the dependence of the upland NPS model (UH utility) and the VFS model (VFSMOD) outputs on certain model parameters and to assist in model calibration. Testing the upland model showed that runoff volume was very sensitive to changes in saturated hydraulic conductivity and initial soil water content. Variations in the Manning's roughness coefficient mainly controlled the time to peak of the outgoing hydrograph and had little effect on runoff volume. The main parameters controlling erosion/sediment yield component were: slope length, slope, soil erodibility, vegetation cover factor, and practice factor.

Testing on the sediment component of the VFS model showed that the width of the vegetative filter strip (i.e. the dimension of the strip in the direction of flow) has the greatest effect on sediment trapping efficiency, followed by 
grass spacing and particle size distribution. The effect of grass height was only visible for large events when the filter began to inundate with sediment. The main parameters controlling the hydrology outputs were saturated hydraulic conductivity of the soil and initial soil-water content; the model was insensitive to changes in the suction-at-the-wetting-front parameter. Variations in the Manning's roughness coefficient mainly controlled the time to peak of the outgoing hydrograph and had little effect on sediment output.

The VFS model VFSMOD (Munoz-Carpena et al., 1999) was calibrated for Ontario conditions using observed field data collected at the Guelph Turf Grass Institute during summer 2000. Computed values of the calibrated model versus the observed field data for sediment flux at the outlet of the filter strip are shown in Figure 18.1. The statistical results from the regression analysis (with $R^{2}=0.90$ ) was encouraging, indicating a highly significant $(p<0.01)$ linear relationship between the observed and predicted sediment flux. PI lines are the $95 \%$ confidence intervals for individual estimates (i.e. prediction limits for new observations).

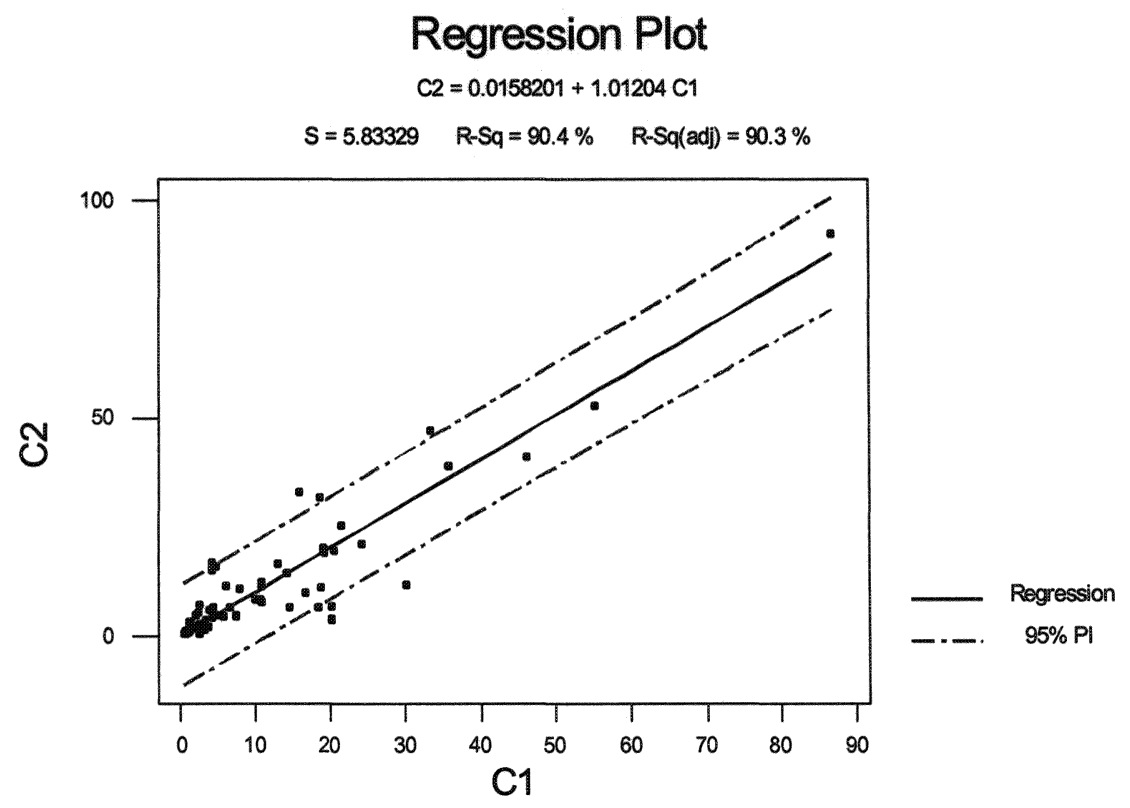

Figure 18.1: VFSMOD (Munoz-Carpena et al., 1999) computed versus observed values for sediment flux at the VFS outlet $(\mathrm{C} 1$ = VFSMOD Computation for Sediment Flux at VFS Exit $\left(\mathrm{g} \mathrm{min}^{-1} \mathrm{~m}^{-1}\right) ; \mathrm{C} 2=$ Observed Sediment Flux at VFS Exit $\left(\mathrm{g} \mathrm{min}^{-1} \mathrm{~m}^{-1}\right)$; and $\mathrm{PI}=95 \%$ prediction limits for new observations). 


\subsection{Conclusions}

VFS can reduce non-point source (NPS) pollution by treating overland flow before it enters streams. The study, when completed, will provide management tools for site specification of VFS based on the soil, land use, land management, and topographic characteristics of the upland area, which are very important formaintaining soil productivity and down-stream water quality. The developed computer models will be useful to consulting engineers and other water management specialist working with farmers to reduce the discharge of pollutants from fields into adjacent streams and creeks. Field experiments on VFS yielded average sediment removal efficiencies between 50 and $98 \%$ for $2.44,4.88,9.76$ and $19.52-\mathrm{m}$ wide filter strips. The first $5 \mathrm{~m}$ of a filter strip is critical and effective in removal of suspended sediments. More than $95 \%$ of the aggregates larger that 40 microns in diameter can be captured within the first $5 \mathrm{~m}$ of the filter strip. However, the remaining smaller size aggregates are very difficult to remove by filtering through grass, as even relatively low levels of turbulent energy in the water is sufficient to keep the finer sediments in suspension. The VFS model VFSMOD (Munoz-Carpena et al., 1999) was calibrated and validated for Ontario conditions using observed data from field experiments. Considering the complex and highly variable nature of the process involved in filtering of sediments through grass, the model has shown good potential in computing sediment removal efficiency of VFS.

\subsection{Needs for Future Study}

Intense or prolonged rainfall events may generate runoff flows that tend to concentrate in flowpaths between vegetative clumps. This concentration or chanellization of flow significantly reduces the removal efficiency of the filter strip. Reinforcement of the natural vegetation with geosynthetic products can reduce flow concentration by spreading the flow across the full cross-section, thus improving the runoff treatment capability of the vegetative filter strip.

In the late-winter/early-spring period when soil is often saturated (low infiltrability) and the vegetation cover is flattened (i.e. dormant season conditions), the efficiency of natural VFS is low. Further studies are needed to determine the effects of sediment load characteristics (e.g. aggregate size distribution), uniformity of distribution of flow across the strip, flowpath length, and flow rate on sediment removal efficiency of VFS. 


\subsection{Acknowledgment}

This research study was funded by the Ontario Ministry of Agriculture Food and Rural Affairs (OMAFRA) and Natural Science and Engineering Research Council of Canada (NSERC). Field experiments were conducted at the Guelph Turf Grass Institute and Environmental Research Centre, Guelph, Ontario, Canada. Technical support and collaboration of the researchers at the Guelph Turf Grass Institute, the Department of Environmental Biology and the Department of Food Sciences of the University of Guelph are highly appreciated.

\section{References}

Applied Research Systems, Inc. (1999), The national conservation buffer initiative: a quality evaluation, Prepared for Natural Resources Conservation Service, Madison, Wisconsin, United States.

Barfield, B. J. , R. L. Blevins, A. W. Fogle, C. E. Madison, S. Inamdar, D. I. Carey, and V.P. Evangelou (1998), Water quality impacts of natural filter strips in karst areas. Transactions of ASAE. 41(2): 371-81.

Barfield, B.J., E.W. Tollner, and J.C. Hays (1978), The use of grass filters for sediment control in strip mining drainage, Vol. I: Theoretical studies on artificial media, Pub. No. 35-RRR2-78. Institute for mining and mineral research, University of Kentucky, Lexington.

Barfield, B.J., E.W. Tollner, and J.C. Hays (1979), Filtration of sediment by simulated vegetation I. Steady-state flow with homogeneous sediment. Transactions of the ASAE 22(5), 540-545.

Bingham, S.C., P.W. Westerman, and M.R. Overcash, (1980), "Effect of Grass Buffer Zone Length in Reducing the Pollution from Land Application Areas", Transactions of the ASAE, 23(2):330-336.

Boyd, P.M., L.W. Wulf, J.L. Baker, and S.K. Mickelson, (1999), "Pesticide Transport Over and Through the Soil Profile of a Vegetative Filter Strip," Proceedings of the 1999 ASAE Annual International Meeting, Toronto, Ontario, Canada, Paper No. 992077.

Choi (1992), Effect of intervening land use on runoff quality, Dissertation submitted to the faculty of the graduate school of the University of Maryland, Maryland, USA, $448 \mathrm{p}$.

Coyne M. S., R. A. Gilfillen, R. W. Rhodes and R. L. Blevins (1995), Soil and fecal coliform trapping by grass filter strips during simulated rain, Journal of Soil and Water Conservation, Vol. 50 (4): pp. 405-408.

Coyne, M.S., R.A. Gilfillen, A. Villalba, Z. Zhang, R. Rhodes, L. Dunn, and R.L. Blevins, (1998), "Fecal Bacteria Trapping by Grass Filter Strips during Simulated Rain," Journal of Soil and Water Cons. 53(2) 140-145. 
Daniels, R. B. and J. W. Gilliam (1996), Sediment and chemical load reduction by grass and riparian filters, Soil Science Society of America Journal, Vol.(60): pp. 246-251.

Dillaha T. A., R. B. Reneau, S. Mostaghimi and W. L. Magette (1987), "Evaluation of nutrient and sediment losses from agricultural lands: Vegetative Filter Strips," US EPA, CBP/TRS 4/87, 93 p.

Dillaha T.A., R.B. Reneau, S. Mostaghimi, and D. Lee (1989), "Vegetative filter strips for agricultural non-point source pollution control," Transactions of ASAE 32 (2), $491-496$.

Dillaha, T.A., J.H. Sherrard, D. Lee, S. Mostaghimi, and V. O. Shanholtz, (1988), "Evaluation of Vegetative Filter Strips as a Best Management Practice for Feed lots," Journal WPCF, Vol. 60, Number 7, 1231-1238.

Edwards, D.R., M.S. Coyne, P.F. Vendrll, T.C. Daniel, P.A. Moore, Jr., and J.F. Murdoch, (1997), "Fecal Coliform and Streptococcus Concentrations in Runoff From Grazed Pastures in Northwest Arkansas," Journal of the American Water Resources Association 33(2) 413-422.

Edwards, D.R., T.C. Daniel, and P.A. Moore Jr., (1996), "Vegetative Filter Strip Design for Grassed Areas Treated with Animal Manures," Transactions of the ASAE, 12(1):31-38.

Federal Interagency Stream Restoration Working Group (1999), Stream corridor restoration: principles, processes, and practices, National Technical Information Service (NTIS), Springfield, Virginia, United States.

Gharabaghi, B., R. P. Rudra, H. R. Whiteley, and W. T. Dickinson (2000a), "Effectiveness of vegetative filter strips in the removal of sediments and pollutants from overland flow", Proceedings of the 28th Annual Conference of the Canadian Society for Civil Engineering, London, Ontario, June 7-10, 2000.

Gharabaghi, B., R.P. Rudra, H. R. Whiteley, and W.T.Dickinson, (2000b), "Improving Effectiveness of Vegetative Filter Strips," American Society of Agricultural Engineers (ASAE), 2000 ASAE Annual International Meeting, July 9-12, 2000, Milwaukee, Wisconsin, USA, Paper No. 002083.

Gharabaghi, B., R.P. Rudra, H.R. Whiteley, and W.T. Dickinson (2001a), "Improving Removal Efficiency of Vegetative Filter Strips", 32nd Annual IECA Conference, International Erosion Control Association (IECA), February 5-9, 2001, Las Vegas, Nevada, USA, page 43-56.

Gharabaghi, B., R.P. Rudra, H.R. Whiteley, and W.T.Dickinson,(2001b),"Performance Testing of Vegetative Filter Strips," World Water and Environmental Resources Congress 2001, Environmental and Water Resources Institute of the American Society of Civil Engineers, May 20-24, 2001, Orlando, Florida.

Hayes J. C. and J. E. Hairston (1983), "Modeling the long-term effectiveness of vegetative filters as on-site sediment controls," Presented at 1983 summer meeting of ASAE, Paper No. 83-2081. ASAE, St. Joseph, MI, 27 p.

Hayes, J.C., B.J. Barfield, R.I. Barnhisel (1984), "Performance of grass filters under laboratory and field conditions," Transactions of the ASAE 27 (5), 1321-1331.

Hill, A. R., (1996), "Nitrate Removal in Stream Riparian Zones," Journal of Environmental Quality, Vol. 25, 743-755.

IJC-PLUARG (1987), Contribution of Phosphorus from Agricultural Land to Streams 
by Surface Runoff, the International Reference Group on Great Lakes Pollution from Land Use Activity, Department of Land Resources Science, University of Guelph, Guelph, Ontario, Canada.

Lalonde, M. N.(1998), Vegetative filter strips: impact of design parameters on removal of non-point pollutants from cropland runoff, M.Sc. dissertation presented to the faculty of graduate studies of the University of Guelph, Guelph, Ontario, Canada.

Lammers-Helps, H., D. M. Robinson and M. H. Miller (1991), Literature review pertaining to buffer strips. Soil and Water Conservation Information Bureau, University of Guelph, Guelph, Ontario, Canada.

Lim T.T., D.R. Edwards, S.R. Workman, B.T. Larson, and L. Dunn, (1998), "Vegetated Filter Strip Removal of Cattle Manure Constituents in Runoff," Transactions of the ASAE, 41(5):1375-1381.

Magette, W. L., R. B. Brinsfield, R. E. Palmer, and J. D. Wood (1989), Nutrient and sediment removal by vegetative filter strips. Transactions of the ASAE, Vol. 32 (2):pp.663-667.

Mickelson, S. K. and J. L. Baker (1993), Buffer strips for controlling herbicide runoff losses, Presented at the 1993 International Summer Meeting, Paper No. 932084, ASAE, St. Joseph, MI, 18 p.

Miller, M.H., J.B. Robinson, D.R. Coote, A.C. Spires, and W. Draper, (1982), "Agriculture and Water Quality in the Canadian Great Lakes Basin: III. Phosphorus," Journal of Environmental Quality 11(3) 487-493.

Moore, Jr., P.A., (1998), "Best Management Practices for Poultry Manure Utilization That Enhance Agricultural Productivity and Reduce Pollution," in: Animal Waste Utilization: Effective Use of Manure as a Soil Resource, Edited by J.L. Hatfield and B. A. Stewart, Sleeping Bear Press, Ann Arbor, Michigan, USA.

Munoz-Carpena, R., J.E. Parsons, and J.W. Gilliam (1999), Modeling hydrology and sediment transport in vegetative filter strips, Journal of Hydrology, 214 (1999) 111-129.

Neibling W. H. and E. E. Alberts (1979), Composition and yield of soil particles transported through sod strips, Presented at the 1979 summer meeting of the ASAE and CSAE. Paper No. 79-2065. St. Joseph, MI, 12 p.

Oelbermann, M. and A. M. Gordon, (2000), "Quantity and Quality of Autumnal Litterfall into Rehabilitated Agricultural Stream," Journal of Environmental Quality, Vol. 29, no. 2, Mar.-Apr. 603-611.

Overcash, M.R., S.C. Bingham, and P.W. Westerman, (1981), "Predicting Runoff Pollutant Reduction in Buffer Zones Adjacent to Land Treatment Sites," Transactions of the ASAE, 24(2):430-435.

Parsons, J. E., R. D. Daniels, J. W. Gilliam and T. A. Dillaha (1990), Water quality impacts of vegetative filter strips and riparian areas, Presented at the 1990 International Winter Meeting of the ASAE, Paper No. 90-2501, ASAE, St. Joseph, MI, $11 \mathrm{p}$.

Patty, L. , B. Rheal and J. J. Gril (1997), The use of grassed buffer strips to remove pesticides, nitrate and soluble phosphorus compounds from runoff water, Pesticides Science, Vol. (49): pp. 243-251.

Robinson, C. A., M. Ghaffarzadeh and R. M. Cruse (1996), Vegetative filter strip 
effects on sediment concentration in cropland runoff, Journal of Soil and Water Conservation, Vol. 50 (3): pp. 227-230.

Rudra, R.P., and G.J. Wall (1986), Quantifying cropland phosphorus losses with rainfall simulation technique, Final report, Supply and Services Canada, Contract No. 24ST.01525-5-0208, Guelph, Ontario, Canada.

Schmitt, T.J., M.G. Dosskey, and K.D. Hoagland, (1999), "Filter Strip Performance and Processes for Different Vegetation, Widths, and Contaminants," Journal of Environmental Quality, Vol. 28, 1479-1489.

Smith, S.J., A.N. Sharpley, and L.R. Ahuja, (1993), "Agricultural Chemical Discharge in Surface Water Runoff", Journal of Environmental Quality 22:474-480.

Srivastava, P. , D.R. Edwards, T.C. Daniel, P.A. Moore Jr., and T.A. Costello, (1996), "Performance of Vegetative Filter Strips with Varying Pollutant Source and Filter Strip Lengths," Transactions of the ASAE, 39(6):2231-2239.

Srivastava P., P.D. Robillard, J.M. Hamlett and R.L. Day (1999), "Watershed Optimization of Best Management Practices Using AnnAGNPS, GIS and Genetic Algorithm," 1999 ASAE/CSAE-SGCR Annual International Meeting, July 18-22, 1999, Toronto, Ontario, Canada, Paper \# 993012.

Thornley, S. and A.W. Bos (1985), "Effects of Livestock Wastes and Agricultural Drainage on Water Quality: An Ontario Case Study," Journal of Soil and Water Conservation, January-February 1985, 173-175.

Van Dijk, P. M., F. J. P. M. Kwaad \& M. Klapwijk (1996), Retention of water and sediment by grass strips, Hydrological Processes, Vol. (10): pp. 1069-1080.

Van Vliet L.J.P., G.J. Wall, and W.T. Dickinson (1978), Soil erosion from agricultural land in the Canadian Great Lakes basin, Ontario Institute of Pedology, University of Guelph, Guelph, Ontario, Canada.

Wall G.J., L.J.P. van Vliet, and W.T. Dickinson (1978), Contribution of sediments to the Great Lakes from agricultural activities in Ontario, Ontario Institute of Pedology, University of Guelph, Ontario, Canada.

Wall, G.J., W.T. Dickinson, and L.J.P. Van Vliet, (1982), "Agriculture and Water Quality in the Canadian Great Lakes Basin: II. Fluvial Sediments," Journal of Environmental Quality 11(3) 482-486.

Wilson, L.G. (1967), Sediment Removal from Flood Water by Grass Filtration, Transactions of the ASAE, Vol. 10, pp.35-37.

Wilson, M. and J. G. Imhof (1998), Literature review: an overview of the state of science. Riparian zone workshop. Grand River Conservation Authority, Cambridge Ontario, Canada.

Young, R.A., R. Huntrods, and W. Anderson (1980), Effectiveness of vegetative buffer strips in controlling pollution from feedlot runoff, Journal of Environ. Quality, 9, 483-487. 